\title{
From Physical Classrooms to E-Learning and Online Teaching: A Case Study of Light International School, Mombasa
}

\author{
Mohan Masaviru \\ School of Communication, Language \& Performing Arts, Daystar University
}

\begin{abstract}
The purpose of the study was to find out how Light International School, Mombasa shifted from physical classroom to online teaching and learning after the Kenyan government suspended on-school learning due to the spread of Covid-19. The study found out that the school swiftly responded by activating on line teaching and learning as from $18^{\text {th }}$ March to $9^{\text {th }}$ April, 2020. The study used content analysis to analyze 30 E-Learning samples from Google Classroom, Zoom and WhatsApp home learning digital platforms. The study used Cohen's Kappa to calculate inter-rater reliability which was $\mathrm{k} .85$ that translates to almost perfect agreement between the two coders. The study concluded that the digital platform or systems used by Light International School, Mombasa were able to apply most of the propositions of Constructivism theory or learning pedagogy. The study recommended that the school can work towards implementing blended learning with a robust ICT infrastructure. Keywords: Light International School, Online teaching, E-Learning, Blended Learning
\end{abstract}

DOI: $10.7176 / \mathrm{JEP} / 11-13-07$

Publication date:May $31^{\text {st }} 2020$

\subsection{Introduction and Background}

With the spread of Corona virus or Covid-19 pandemic across the world, many governments issued directives to close schools to contain its spread. In Kenya, all schools were directed to close on Monday, 16 ${ }^{\text {th }}$ April 2020. Therefore, learning in all government and private schools was stopped immediately. This directive affected Light International School, Mombasa as well. The study makes note that when the directive was issued, the school term was 5 weeks away to official closing date. The directive, therefore, affected the school term's academic calendar as it was unanticipated.

Due to the unexpected closing of schools, the idea of home learning and online teaching/ E-Learning became a reality as many schools in developed countries had already started embracing online teaching or home learning sessions. This was inevitable for Light International School, Mombasa.

\subsection{Light International School, Mombasa - An overview}

Light International School, Mombasa is in Nyali Estate off Greenwood drive. It is an international school that offers the British National Curriculum and students sit the Cambridge Assessment International Education examinations. The school has Early Years that follow the IEYC (International Early Years Curriculum), IPC (International Primary Curriculum) and IGSCE in senior school. The combined curriculum offers opportunities for students to broaden their academic horizon through a variety of subjects and rich co-curricular activities being offered at Light International School, Mombasa (www.lis.sc.ke/mombasa). The school is co-educational institution with a population of over 350 students and about 55 teachers.

\subsection{E-Learning/ Online Teaching}

According to Stanford University, Online teaching typically refers to learning that is delivered completely online which means there are no physical classes or on-school class sessions. According to Joshua Stem (n.d) online teaching and E-Learning is the newest and most popular distance education that takes place over the internet. He adds that several digital platforms have been used to facilitate online teaching and E-Learning. These include correspondence with emails, radio, television, CD ROM, internet based, mobile learning such as cellular phones etc (http://www.sloan-c.org/resources/index.asp). With the spread of Corona Virus around the world, UNESCO released a list of helpful digital learning systems that schools could use.

According to UNESCO, digital learning management systems can be Google Classrooms, ClassDojo, CenturyTech, Edmodo, Edraak, EkStep, Moodle, Nafham, Paper Airplanes, Schoology, Seesaw, Skooler. It adds mobile phones based digital platforms such as Cell-Ed, Eneza Education, Funzi, KaiOs, Ubongo, Ustad Mobile, Kolibri, Kitkat School, Byju's, YouTube and Rumie. UNESCO also mentions Massive Open Online Course (MOOC) platforms that also support online teaching and E-Learning. Among the online live-video platforms, UNESCO mentions Dingtalk, Lark, Hangouts Meet, Teams, Skype and Zoom (www.en.unesco.org/covid19/educationresponse/solutions). As noted above, there are many online platforms that schools can make use of in place of physical classrooms. Accordingly, it depends on the suitability of each digital platform selected. This is because not all digital learning management systems can meet the demands of a school based on population, demographic factors, IT infrastructure, the benefits and the unique challenges of the E- 
learning systems as well.

Heap (2017) reports that online teaching and E-Learning allows the learners to have flexible schedule and environment because students select their own learning environment whether a gym, bedroom or café. He adds that the students don't need to commute to attend lessons. Secondly, Heap posits that online teaching and learning builds on self-discipline and responsibility on the part of the student since students have to be self-motivated and good at time management skills also. There are many other advantages of online platforms as compared to physical classrooms however there are also challenges that come with virtual learning environment (http://online.illinois.edu/articles/online-learning/item/2017/06/05/5).

Gillet (2017) reported that technological competence and confidence are challenges for both the teacher and the student. He adds that frustration can set in for the teacher, students and the community where their technology capacity is little. Secondly, he mentions that some digital platforms have limited functionality that limits or slows down interactions between the teacher and the students or the community.

\subsection{Problem Statement}

The spread of Covid -19 pandemic in Kenya saw the government directing the closure of all learning institution with no reference to when the schools will reopen. The government directive affected Light International School, Mombasa and as noted above the academic term was still ongoing with 5 weeks remaining before closure on the $9^{\text {th }}$ April, 2020. Consequently, the directive immediately disrupted physical classrooms or on-school learning sessions and the only option was online teaching and E- Learning. The study is therefore concerned with how Light International School, Mombasa was able to activate its IT action plan in order to respond to the crisis and ensure learning is undisrupted for the 5 weeks that were due.

\subsection{Objectives}

1. To examine the E-Learning systems used by teachers at Light International School, Mombasa.

2. To determine the future of E-Learning opportunities for Light International School, Mombasa.

\subsection{Literature Review}

In a study by Baig (2011), Online Learning Environment (OLE) is defined as a set of teaching and learning tools designed to enhance student's learning experiences by having a computer and internet connectivity. The study posits that the use of OLE give students the opportunity to use several web related features such as video conferencing and communicative space which make it more interactive. The study reports that Web 2.0 provides digital resources by helping learners to search, share and ensures collaborative learning that surpasses the traditional classroom (Baig, 2011).

On Social Networking Sites (SNS), the study reports that there are too many sites to select from (Baig, 2011). The study mentions Blogs, Email, Listserv, Discussion Forum, Second Life and Virtual Classroom. The SNS provides opportunities for students to communicate, share, work together and publish their ideas with high sense of organization. Other SNS such as WhatsApps, Telegram, and Google Classroom also have features that allow the students to share, communicate and post their work depending on their flexibility. Tamargo (n.d) observed that physical classrooms are inhibiting as compared to E-Learning classroom. He posits that the structure of physical classrooms is pressurizing and intimidating whereas the online classroom encourages freedom of expression and students are more open to communicate and express their opinions. The study concluded that using Wiziq Online classroom has many advantages than the traditional physical classroom. The advantages ranged from improved subject performance, one-on-one attention is emphasized as compared to whole class, students have access to a lot of online resources, and it also has many features including video and text chatting on a given topic among others (Baig, 2011).

$\mathrm{Lu}$ and Hao (2014) study was interested in finding out factors that impacts primary students' use of ELearning. The study classified the factors into two areas: individual factors and context factors.

Individual factors included gender differences where the study observed that boys spend most of the time on the computer as compared to the girls which gives the boys an advantage when it comes to stronger computer skills. Secondly, age was also a factor. The study posits that older children (15-18years) spend more time on the internet as compared to the young children (9-12years). Therefore, internet use tends to be popular as students enter adolescence. The third factor was academic performance. Studies have found out that heavy users of internet especially young students (9-13years) tend to generally have lower grades as compared to older students (15-17 years) $\mathrm{Lu}$ and Hao (2014).

Context factors included social-economic status which includes family income, parental education and offline home activities. The study found that family income is related to home internet access. According to Livingstone and Bober (2004 as cited in Lu and Hao (2014) 88\% of middle class children had home internet access as compared to $61 \%$ of working class children. The study however notes that the gap is being narrowed because ICT devices are now affordable. According to OECD (2012 as cited in Lu and Hao (2014), more than 95\% of teenagers in 
Europe have access to at least one internet-connected device at home.

Family level of education also determines the type of online activities the children engage in while online. The study reported that students from well-educated families were more likely to try new internet activities (Lenhart et al. 2007 as cited in Lu and Hao (2014). However, the study concluded that the digital divide has been narrowed and the main concern has shifted to learning divide ( $\mathrm{Lu} \& \mathrm{Hao}, 2014)$.

In another study by Roddy et al., (n.d), it was reported that online learning has benefits compared to physical classroom or face-to-face teaching. They however observe that teachers need to apply best practices by acquiring critical competencies. The competencies are communication skills, technological competence, provision of informative feedback, administrative skills, responsiveness, monitoring learning and providing student support. The above mentioned teacher competencies will ensure reasonable intensive online environment.

Roddy et al., (n.d) also noted that there are also a number of factors that can act as barriers or challenges on the part of the student. These barriers are: technical difficulties, perceived isolation, challenges balancing study, confusion with content, poor academic performance or lack of motivation.

\subsection{Constructivism Theory}

The Constructivism theory has been with us for decades and the assumption that the theory makes in education is learners construct their own knowledge individually and collaboratively. Piaget's theory focuses on knowledge construction because learners acquire knowledge through their actions. It also makes the assumption that learners must use their pre-existing knowledge and skills to solve problems.

Constructivism approach in class emphasizes on learner centered, learner directed and collaborative style of teaching learning process. The teacher hence becomes a motivator, guide and a resource person. The teacher proposes activities that are meaningful for the learners to reflect, research and be creative. The learning tasks supplement lecture as the learners construct their own meanings (Dagar and Yadav, 2016).

In Constructivism pedagogy, learning involves an active process where learners construct new knowledge by relating to what they already know. The constructivist learning strategies avoid directing learners towards the solution to the problem as teachers pose the challenge and offer support and motivation (Dagar and Yadav, 2016). The constructivist pedagogy also allows the teacher to use multiple multimedia to enrich the learning environment and supporting classroom tasks. The constructivist classroom is also identified by the percentage of the time spent on student centered activities whereby the constructivist pedagogy ensures that class time is dominated by learner centered activities (70\%) as reported by Forman et al., n.d as cited in Dagar and Yadav, 2016).

According to Dagar and Yadav (2016), Constructivism emphasizes on four aspects of knowledge acquisition. There are:

1. Knowledge construction rather than knowledge transmission

2. New learning builds on prior knowledge

3. Learning is enhanced by social interactions

4. Meaningful learning develops through authentic tasks

\subsection{Research Methodology}

The study made use of Case Study design. A case study design is an in-depth study of a particular research problem or contemporary phenomenon rather than a survey. It is used to narrow down a very broad field of research into one researchable example and focuses on the dynamics of the case within its real life context (De Poy \& Gitlin, 2016; Teegavarapu \& Summers, 2008). Therefore, case study design allows the researcher to have in depth contextual analysis of that researchable case. The design provides detailed descriptions of specific cases.

Triangulation of data as recommended by case study design allows the researcher to use different data collection techniques which assures the validity of research. Triangulation was done by asking teachers to briefly describe what they were posting on the groups. Case study therefore achieves construct validity by using multiple sources of evidence. Whereas, internal validity is achieved through content analysis which involves matching patterns and using detailed explanations (Teegavarapu \& Summers, 2008).

\subsection{Case Study Process}

The figure below outlines how the study used case study research design when conducting the research. 


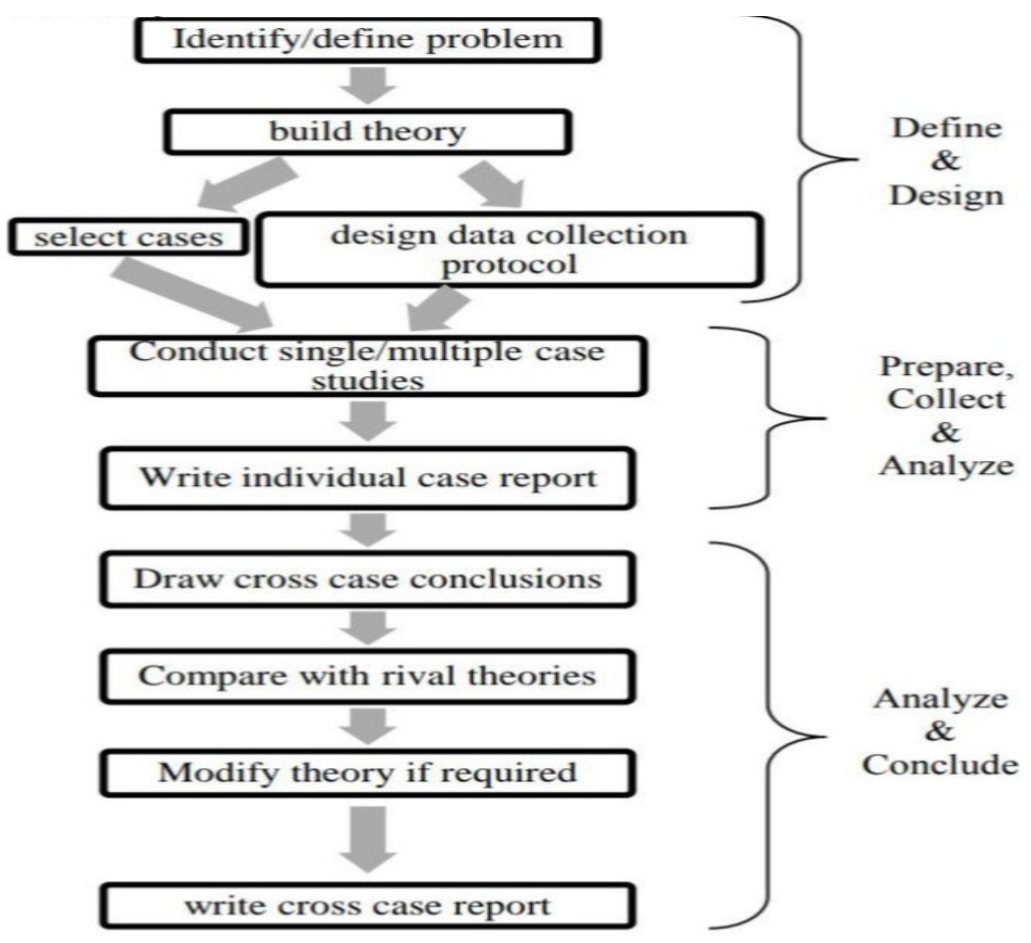

Figure 1: Case Study Method: Teegavarapu \& Summers (2008).

The study used purposive sampling in selecting units to be involved in the research. According to Orodho (2009), purposive sampling allows the researcher to use his own expertise or experience in selection units that are representative or typical of the population. The units selected are based on a certain criteria. This study selected participants to share their lesson materials based on the knowledge of those who were using different E-Learning systems. The study used purposive sampling because of the Covid-19 pandemic and therefore using probability sampling proved a challenge as many teachers were unreachable because of stay-home directive. Purposive Sampling was also selected because it is mostly used in qualitative study which makes it appropriate for the current study as the researcher worked with qualitative data as compared to quantitative (Etikan, Musa and Alkassim, 2015).

Purposive sampling was used in selecting participants who used Zoom and Google Classrooms E-Learning platforms to deliver their online teaching and learning at Light International School, Mombasa. A total of 5 teachers were asked to provide their Google classroom and Zoom sample lessons for content analysis. A total 24 E-Learning lesson materials were sampled and 6 WhatsApp groups were also accessed for content analysis. The sampled E lesson materials covered E-learning and online teaching for the period of $18^{\text {th }}$ March to $9^{\text {th }}$ April, 2020.

There was also unstructured interview with the nursery coordinator over the phone about how they used WhatsApp groups in International Early Years Curriculum. The use of sampled E-Lesson materials, WhatsApp groups and unstructured interview allowed for triangulation of data which ensured validity of the research.

\subsection{Content Analysis}

Contents analysis is a research method for studying documents, pictures, images audio or video. Content analysis is used to examine patterns in the sampled documents by identifying patterns and assigning codes. The assigned codes enable the researcher to analyze meanings of content within texts, videos, audio and any other documents (Prasad \& Bhaskaran, 2008). The coding sheet will be adapted from theory of constructivism as well as deriving coding schemes from the data sampled and compared to context, meanings, texts and intentions contained in the sample lessons retrieved from the E-Learning platforms of Light International School, Mombasa. The role of coding was to put information sampled into a quantifiable form for analysis purposes (Parveen \& Showkat, 2017). The units of analysis in the study were words, sentences, phrases, images, statements contained in the sampled ELearning lessons. To ensure reliability, two trained coders were used to assign codes and identifying coding schemes from the sampled E-Learning lessons. The coding exercise was discussed, repeated to ensure consistency and accuracy of the research findings (Masaviru, 2016).

\subsection{Coding Sheet}

Cohen's Kappa was used to test for inter-rater reliability. Cohen's Kappa was used because it is a statistical coefficient that measures the degree of accuracy and reliability between two raters. As noted by (McHugh, 2012; 
Swert, 2012), Cohen's Kappa takes into account the degree of disagreement between the raters whereby agreement indicates the percentage of matches between the coders on assigned values.

Cohen's Kappa $\frac{k=n_{a}-n_{s}}{n-n_{s}}$

Where $\mathrm{n}=$ number of subjects

$\mathrm{n}_{\mathrm{s}}=$ number of agreement due to chance

$\mathrm{n}_{\mathrm{a}}=$ number of agreement

Kappa is always less than or equal to 1 . A value of 1 implies perfect agreement and values less than 1 imply less than perfect agreement between the coders. However, McHugh (2012) advises on the criterion below when interpreting the Cohen's Kappa.

$\leq 0=$ no agreement

$.01-.02=\quad$ slight agreement

$.21-.40=\quad$ fair agreement

$.41-.60=\quad$ moderate agreement

$.61-.80=\quad$ substantial agreement

$.81-1.00=\quad$ almost perfect agreement

\subsection{Calculating Cohen's Kappa}

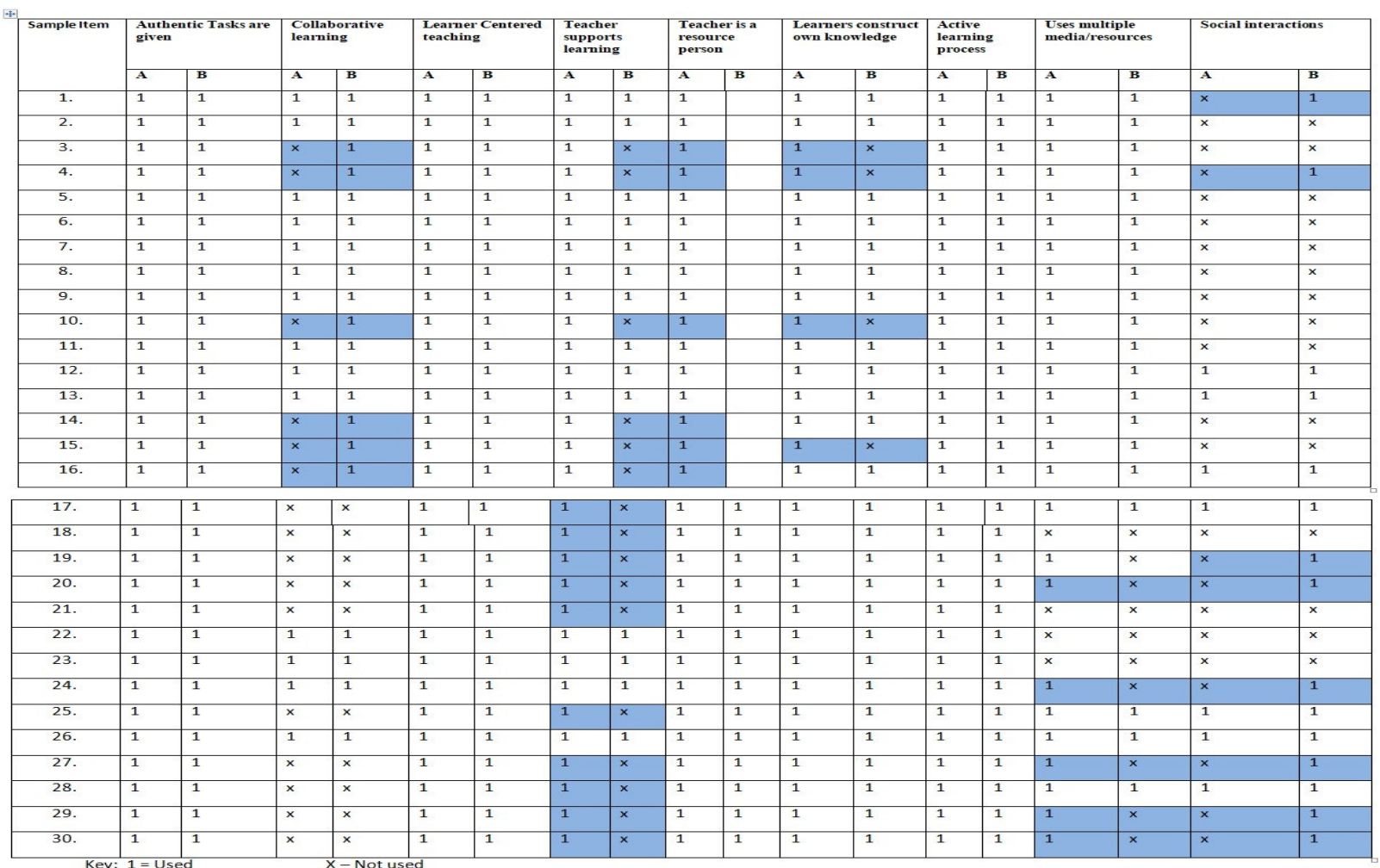

Total Coding $=270$

Figure 2: Summary of Coder A and B Sheets

Agreement $=231$

Disagreement $=39$

Therefore percentage agreement $=\quad \frac{231}{270} \times 100=85.6 \%$

Percentage Disagreement $=\frac{39}{270} \times 100=14.4 \%$

Percentage of Agreement due to chance

Coder $\mathrm{A}=19 \times 100=7.04 \%$

$$
270
$$

Code $\mathrm{B}=\frac{20}{270} \times 100=7.41 \%$

Total number of agreement du to chance $=7.04 \times 7.41 \times 100=5.22 \%$ 
Number of cases due to chance therefore was $=5.22 \times 270=14.1$

Cohen's Kappa $\frac{\mathrm{k}=\mathrm{n}_{\mathrm{a}}-\mathrm{n}_{\mathrm{s}}}{\mathrm{n}-\mathrm{n}_{\mathrm{s}}}$

$\mathrm{k}=\frac{231-14.1}{270-14.1} \quad=\frac{216.9}{255.9}=0.85$

$\mathrm{k}=.85$

As noted in McHugh (2012) interpretation criterion, inter-rater reliability is almost perfect agreement.

\subsection{Discussion}

4.1 E-Learning systems used by teachers at Light International School, Mombasa

Light International school used a multimedia approach to their E-Learning and online teaching. There had several E-Learning systems that included Zoom, Google Classrooms and WhatsApp group chat.

4.1.1 Zoom Classrooms/Meetings

A number of teachers used Zoom as an E-Learning system to organize for live sessions with students. The use of Zoom live classrooms was mostly done by secondary teachers depending on the nature of the lessons and the students. Sample 3 E- Learning lesson, shows that the teacher invited students to a zoom meeting (Meeting ID 304-759-0867) as an extension to a discussion that started on their google classroom. In this context Zoom classrooms depend so much on features that zoom has. Students are invited to a scheduled meetings/online classrooms therefore creating a virtual learning environment. The presence of a camera, video and chat features on Zoom clearly replicates face-to-face classroom scenario where discussion, collaboration, active learning pedagogy are evident through the use of teacher assigned authentic tasks.

In relation to constructivism theory, the sample lesson 3 shows that teachers at Light International School (LIS) Mombasa used multimedia to enrich the learning environment and supporting classroom tasks. Sample 10, 11 and 12 E- Learning materials show that constructivism pedagogy was achieved because the teacher gives authentic tasks (using questions) and the teacher is able to follow up with calculations. The aspect of the teacher being a resource person is evident because the tasks given in all Zoom live classrooms samples show that constructivism pedagogy of the teacher providing support to learners, teaching is learner-centered, learners construct own knowledge through tasks given and learning is active.

4.1.2 Google Classrooms

Google Classrooms was used by teachers in secondary school. According to the samples 1, 3 and 4 E- learning lessons, learning was learner centered because the teacher gives instruction on what is to be done by the learners. The samples also reflect constructivism learning pedagogy because there is collaboration through the discussion between the teacher and the student. A closer look at samples 3 and 4, reflect constructivism learning pedagogy since the teacher uses multiple media resources such as YouTube videos and booklet to ensure that learners are actively involved in the tasks given as they construct own knowledge. The instructions given are learner centered and the teacher's role is to post resources and a support to the learners as noted in the discussion forum.

Samples 5, 6, 7, 8 and 9 are also google classrooms. According to these samples, it is clear that authentic tasks are given by the teachers. Several tasks are assigned which is an indication that teachers gave tasks therefore meeting constructivism pedagogy by using tasks that make learners construct their own knowledge. Samples 15 to $24 \mathrm{E}$ learning lessons also are rooted in constructivism learning pedagogy. The teachers have assigned tasks using multiple media or resources. The resources include exams, quizzes, videos, revision papers, PowerPoint, reading notes and questions. The tasks are learner centered as teachers on Google Classroom play the role of the resource person as learners construct their own knowledge. The E-learning lesson samples indicate that students are actively involved in meaningful tasks. As supported by Dagar and Yadav (2016), constructivist pedagogy is the approach that allows teachers give activities or tasks to students that are meaningful for them to reflect and be creative. Therefore, these activities or tasks supplement lecture. Dagar and Yadav (2016) assert that assessment in constructivist learning process is based on real-life tasks and performance assessment that require students to complete learning assignments given. The sampled E-learning lessons (samples18, 17, 21, 16, 24) show that teachers have assigned tasks that are assessed and graded based on completion of tasks.

4.1.3 WhatsApp E-Learning Classrooms

WhatsApp being a popular social media platform was put to use in primary and nursery schools of Light International School. The WhatsApp feature of forming groups and adding members using phone numbers was used by teachers in primary and nursery. However, the groups had privacy activation whereby only the admins (subjects and class teachers) could post tasks to be completed. The learners (other members) could only view, download the tasks, complete the task then directly message the subject teacher for marking and feedback sessions.

E-learning lesson samples 25-30 show that teachers gave tasks using multiple media/resources. Teachers used educational videos from internet, worksheets, personal recorded videos, personal recorded voices, quizzes 
and educational links. The tasks came with instructions on what should be done. With reference to constructivism learning pedagogy, authentic tasks are important and a closer look at the E- learning lesson samples 25-30 majority of the time was spent on students' active involvement in the tasks. This is supported Forman et al., n.d as cited in Dagar and Yadav (2016) who posited that constructivism classroom is dominated by learner centered activities which translates to $70 \%$ of class engagement.

As noted the samples 25-30, the teacher is a resource person or a motivator to the learners in the process of knowledge construction. The teacher also supports the learners through the tasks as interaction is encouraged through listing or calling out names of the students in class. The E-learning samples 25-30 indicate that all but collaborative learning and social interactions tenets of constructivism learning pedagogy are evident in all the lessons. Learners are actively involved in authentic tasks that are learner centered when they are in the process of own knowledge construction. As noted in the samples, learning develops through authentic tasks building on prior knowledge as learners construct new knowledge which is supported by Dagar and Yadav (2016).

\subsection{The future of E-Learning opportunities at Light International School, Mombasa}

As noted above, Light International School, Mombasa was able to respond very fast immediately the Covid-19 pandemic forced the closure of schools in Kenya. The effects of Covid-19 left many schools and organizations vulnerable and this is a pointer to how natural disasters or calamities can have great impact to schooling. However, as the entire world is trying to contain the spread of Covid-19 pandemic, there have been many opportunities in many fields. People, governments, organizations and institution such as schools are coming up with solutions to remain relevant. Remote learning, distance learning, online learning or E-Learning has been with us for decades but mostly in higher institutions of learning such as colleges or universities.

\subsubsection{Blended Learning}

According to several scholars, blended learning refers to the integration of face-to-face and online instruction therefore reducing physical classroom seat time for learners (Dziuban et al., 2018). Blended learning can also be defined as a hybrid or mixed mode learning where part of the face-to-face instructions are replaced by online learning. Sloan Consortium extends the definition of blended learning further by specifying that $30 \%-70 \%$ of instruction is delivered online (Linda and Baiyun, ). Lalima and Kiran (2017) define blended learning as an approach that incorporates traditional teaching and ICT supported learning that includes both online and offline learning.

Blended learning as defined by several scholars is a hybrid system that combines internet and digital media with established face-to-face classrooms that allows the physical presence of the students and the learners Bryan and Volchenkova (2016). Blended learning combines direct instructions from the classroom as well as online teaching and learning hence students gain advantage of online learning but still maintain the social interaction and the human touch that comes with face-to-face classrooms. Students also gain a lot from blended learning because the constant interaction with ICT, online as well as offline makes them better at digital fluency. Blended learning has many benefits one major one being schools can take advantage of the flexibility and convenience of online learning and teaching while still retaining the advantages of face-to-face classroom experience. Blended learning can also act as bridge when it comes to distance, flexibility and convenience of teachers and learners.

The adoption of Firefly application, Zoom Live sessions, WhatsApp learning groups at Light International School, Mombasa is important because it opens opportunities for blended learning. The creation of digital content on Firefly application, equipping teachers, parents and students with relevant digital skills mirrors a new online and teaching paradigm shift at the school.

The benefits of blended learning at Light International School, Mombasa are:

- The school may increase enrollment of students from all parts of the world because the school can have virtual classes.

- Teachers and students will experience both modes therefore becoming techno savvy and increasing digital fluency that is an important $21^{\text {st }}$ century skill.

- Students will be able to construct own knowledge rather than consuming it therefore achieving the propositions of Constructivism Theory.

- The human touch is maintained since students interact with teachers and other learners in the face-to-face classroom as well interacting with the subject content/resources on the online platform.

- Blended learning is child-centered. The education philosophy and pedagogy is shifting to child-centered learning approaches to maximize to the universal goals of teaching and learning.

The implementation of blended learning at Light International School, Mombasa is an educational sound decision with various factors to be considered to ensure the successful implementation of the same. There are four models that can be considered and several questions to be thought through before fully implementing blended learning

The first one is rotation model where students rotate between completing tasks online and face-to-face classrooms. The rotation model has different variants such as the flipped classroom. The second one is flex model 
where students mainly study online according to individually customized learning schedule while face-to-face support is given by the teacher when required. The third one is self-blend where student supplement their face-toface studies by taking additional online course away from school. The fourth one is the enriched virtual model where learning is mainly online with occasional visits to face-to-face classes for tuition (Bryan and Volchenkova, 2016).

Questions to critically think about when considering blended learning are

1. How will the management and faculty consider which components (subjects and subject content) will occur online and which components will be done in face-to-face classrooms?

2. How will the management and faculty manage the relationship between components offered online and those that occur face-to-face?

3. How often will faculty/teachers meet with the students face-to face?

4. How many hours per week will the students be engaged online?

These four questions are among the many school management and faculty need to think about before fully implementing blended learning.

\subsubsection{Conclusion}

The student concluded that Light International School, Mombasa was able to activate online classroom the moment the government of Kenya directed the suspension of learning. The move from physical classroom to e-Learning or online teaching has developed structure that can be improved upon.

The digital platform used: Zoom, Google classroom and WhatsApp ensured that authentic tasks given were learner centered and involved active participation of students. The teachers' role was to act as a resource person as well a motivator. Students were involved in construction of knowledge through the tasks given by the teachers.

The Cohen' Kappa of k .85 indicates that the online teaching and learning met the Constructivism pedagogy of learning as the two coders had a slight chance of disagreement (14.4\%). Therefore, it is important to report that online teaching and learning maintained several aspects of face-to-face classroom (physical classroom).

The concept of blended learning can be adopted by Light International School, Mombasa with a clear structure on how to implement. Blended learning will allow the school to adopt better practices in order in to improve learning outcomes. This is achievable through the use or Firefly Application.

4.2.3 Recommendations

The study makes the following recommendations:

- The school should implement blended learning to ensure that learning remains uninterrupted even when calamities such as earthquakes, tsunami, pandemics and any other natural disasters occur.

- The school should have IT action plan and effective ICT infrastructure that can be immediately activated across the entire school to reach all parents and students without any technological problems.

- The school should invest in very robust digital professional development courses for all the teaching and nonteaching staff.

- The school should design a blended model customized to meet their educational needs

\section{References}

Baig Muntajeeb (2011) A critical Study of Effectiveness of Online Learning Students' Achievement

Bryan, A., and Volchenkova, K., N. (2016). Blended Learning: Definition, Models, Implications for Higher Education. Bulletin of the South Ural State University. Ser. Education. Educational Sciences 8 (2) 24-30.

Dagar, V., and Yadav, A. (2016). Constructivism: A Paradigm for Teaching and Learning. Arts and Social Science Journal 7, (4)

De Pop E., and Gitlin, L (2016). Introduction to Research

Dziuban, C., Graham, C., Moskali, P., Norberg, A., Sicilia, N. (2018). Blended Learning: the new normal and emerging technologies. International Journal of Educational Technology in Higher Education

Etikan, I., Musa, A., and Alkassim, R. (2015). Comparison of Convenience Sampling and Purposive Sampling. American Journal of Theoretical and Applied Statistics 5 (1)1-4 www.sciencepublishinggroup.com/j/ajtas

Gillet, J. (2017). The Challenges of Online Learning: Supporting and Engaging the Isolated Learner

Heap, T (2017). The 5 benefits of studying-online-(vs.-face-to-face-classroom)

http://online.illinois.edu/articles/online-learning/item/2017/06/05/

https://teachingcommons.stanford.edu/gallery/fully-online

http://www.sloan-c.org/resources/index.asp

https://en.unesco.org/covid19/educationresponse/solutions

Krippendorff, K. \& Hayes, A. (2007). Answering the call for standard reliability measure for coding data. Communication Methods and Measures 1, (1) 77-89.

Lalima, Kiran, L., D. (2017). Blended Learning: An Innovative Approach. Universal Journal of Educational Research 5 (1), 129-136.

Linda, F., Baiyun, C., Blendkit Reader: Understanding Blended Learning 3rd edition 
Mc Hugh, M(2012). Inter rater reliability: Kappa statistics. Biochem Med, 22 (3) 276-282 www.biochemmiedica.com/

Masaviru, M., (2016). Image Restoration: From Theory to Practise: the Case of Manny Pacquiao and Nike Company. New Media and Communication (51)

Parveen, H., Showkat, N. (2017). Content Analysis. Media and Communication Studies

Prasad, D., Bhaskan, V. (eds) (2008). Research Methods for Social Work, New Delhi: Rawat pp.173-193. Content Analysis. A method of Social Science 1Research.CSS.

Lu, J. and Hao Q. (2014). What factors impact primary students' engagement for learning and entertainment at home. Journal of Computers in Education Vol 1 (133-150)

Roddy C, et al. (n.d). Applying Best Practice Online Learning, Teaching and Support to Intensive Online Environments: An Integrative Review.

Stem, J (n.d) Introduction to online teaching and learning

Swert, D., K. (2012). Calculating inter-rater reliability in Media content analysis using Krippendorff's Alpha. University of Amsterdam.

Tamargo F. (n.d). Virtual Instruments and Tools

Teegavarapu, S., \& Summers, J. (2008). Case study method for Design Research. International Design Engineering Technical Conferences and Computers and Information in Engineering Conference August 3-6 2008, New York, USA

www.lis.sc.ke/mombasa

\section{APPENDIX 1: CODING SHEET}

Please go through the sampled E- Learning lessons and assign 1 if you identify the content and $\mathrm{X}$ if the content is not used. Please not that you are only checking for only appearance of the content not how many times it has been used.

\begin{tabular}{|l|l|l|l|}
\hline Content & Used $=\mathbf{1}$ & Not used $=\mathbf{X}$ & Description \\
\hline Authentic Tasks are given & & & \\
\hline Collaborative learning & & & \\
\hline Learner Centered teaching & & & \\
\hline Teacher supports learning & & & \\
\hline Teacher is a resource person & & & \\
\hline Learners construct own knowledge & & & \\
\hline Active learning process & & & \\
\hline Uses multiple media/resources & & & \\
\hline Social interactions & & & \\
\hline
\end{tabular}


APPENDIX 2: SUMMARY CODING SHEET

\begin{tabular}{|c|c|c|c|c|c|c|c|c|c|}
\hline Sample Item & $\begin{array}{l}\text { Authentic Tasks are } \\
\text { given }\end{array}$ & $\begin{array}{l}\text { Collaborative } \\
\text { learning }\end{array}$ & $\begin{array}{l}\text { Learner Centered } \\
\text { teaching }\end{array}$ & $\begin{array}{l}\text { Teacher } \\
\text { supports } \\
\text { learning }\end{array}$ & $\begin{array}{l}\text { Teacher is a } \\
\text { resource } \\
\text { person }\end{array}$ & $\begin{array}{l}\text { Learners construct } \\
\text { own knowledge }\end{array}$ & $\begin{array}{l}\text { Active } \\
\text { learning } \\
\text { processs }\end{array}$ & $\begin{array}{l}\text { Uses multiple } \\
\text { media resourres }\end{array}$ & Social interactious \\
\hline 1. & & & & & & & & & \\
\hline 2. & & & & & & & & & \\
\hline 3. & & & & & & & & & \\
\hline 4. & & & & & & & & & \\
\hline 5. & & & & & & & & & \\
\hline 6. & & & & & & & & & \\
\hline 7. & & & & & & & & & \\
\hline 8. & & & & & & & & & \\
\hline 9. & & & & & & & & & \\
\hline 10. & & & & & & & & & \\
\hline 11. & & & & & & & & & \\
\hline 12. & & & & & & & & & \\
\hline 13. & & & & & & & & & \\
\hline 14. & & & & & & & & & \\
\hline 15. & & & & & & & & & \\
\hline 16. & & & & & & & & & \\
\hline 17. & & & & & & & & & \\
\hline 18. & & & & & & & & & \\
\hline
\end{tabular}

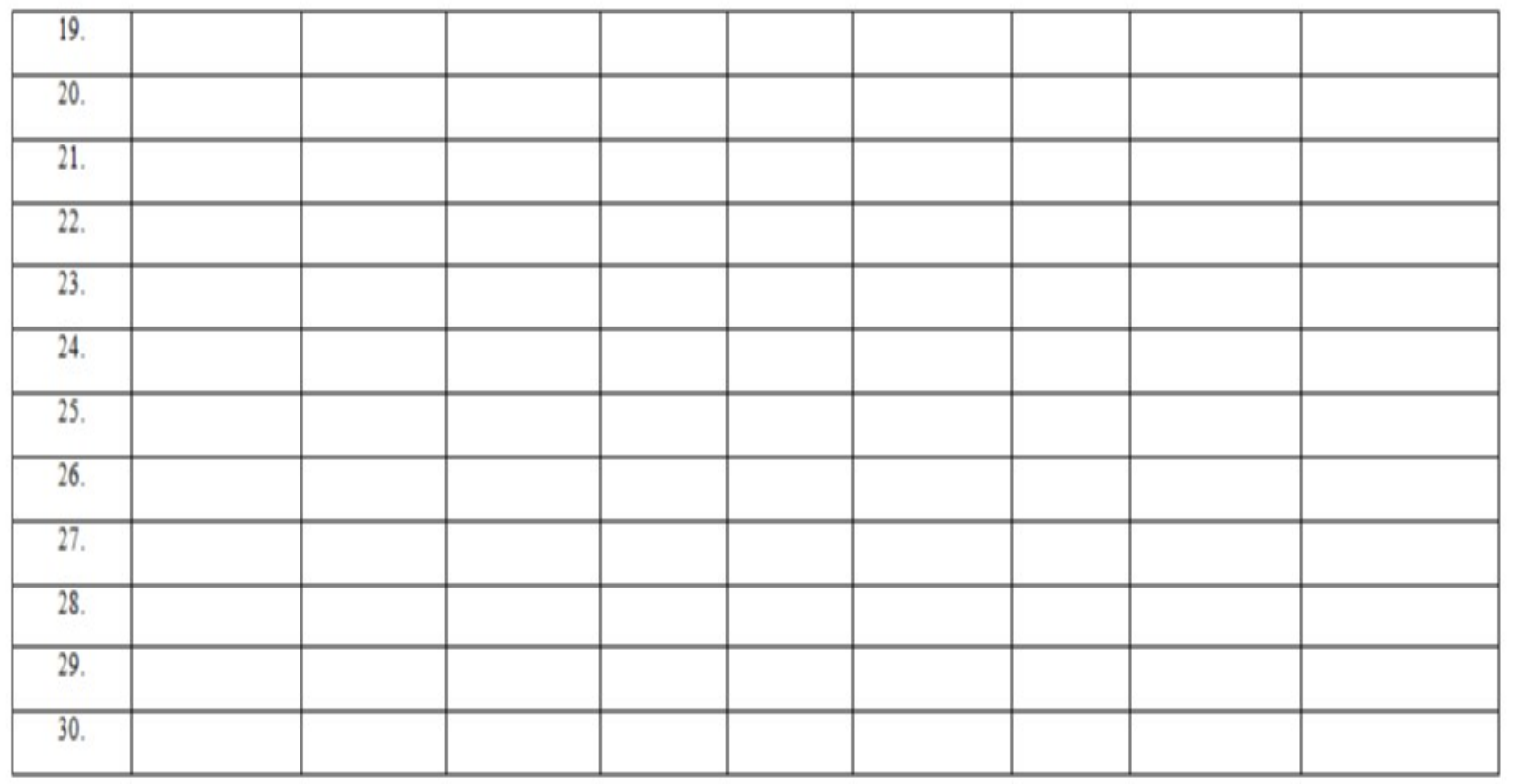




\section{APPENDIX 3: E-LEARNING LESSON SAMPLES}

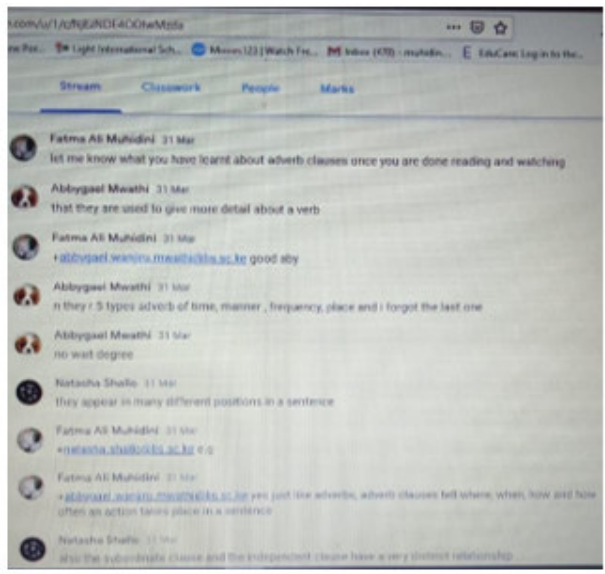

Sample 1

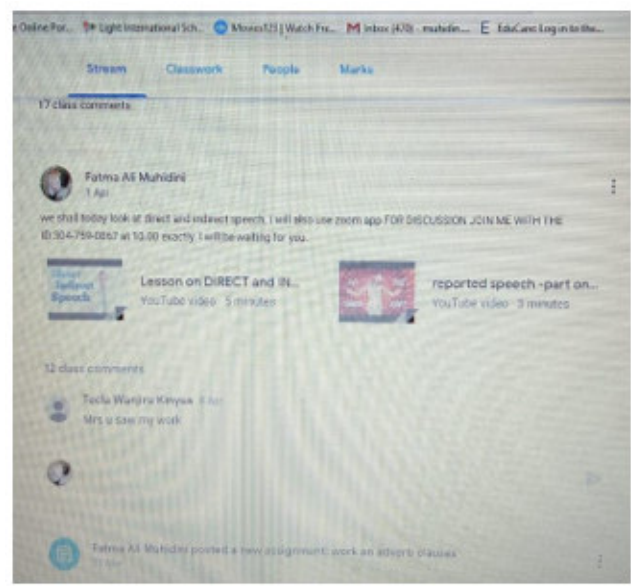

Sample 3

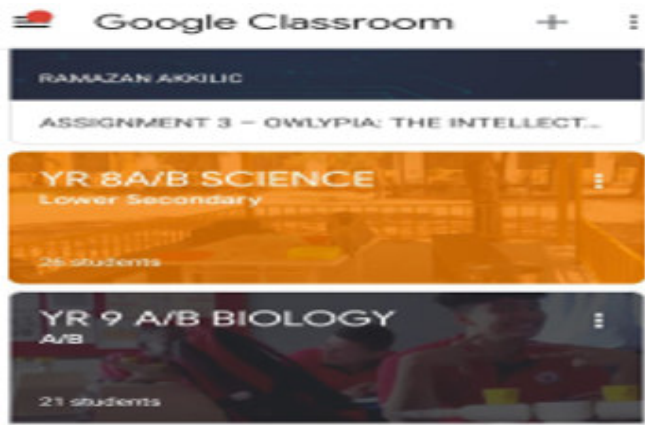

CHEOKPOINT OCT $2018 \mathrm{PP}$

CHECXPOINT OCT 2OMBPI

Sample 5

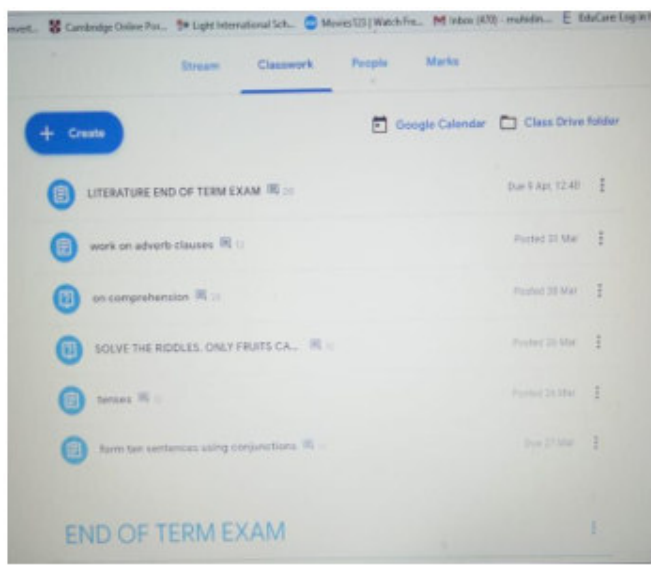

Sample 2

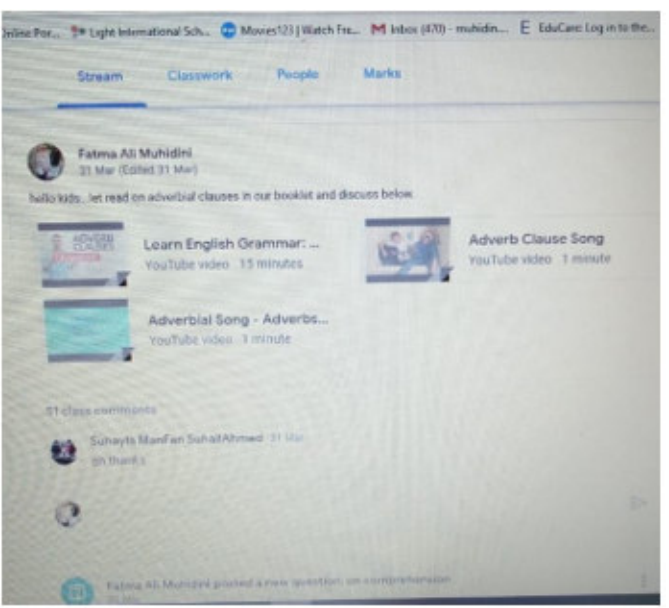

Sample 4

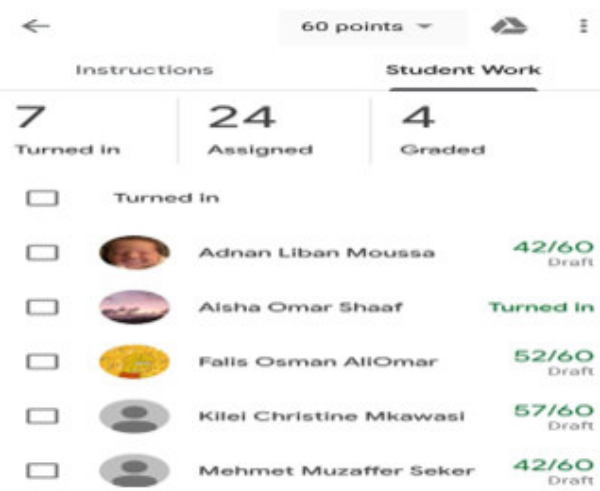

Sample 6 


\begin{tabular}{|c|c|c|c|}
\hline$\cong$ & YR 10 BIOLOGY & \multicolumn{2}{|c|}{ 욤 } \\
\hline \multicolumn{4}{|c|}{ Anode Saphan Ochieng } \\
\hline 8 & DANIEL KIMILU & & : \\
\hline 8 & Ignatius Mathew Opiyo & & s \\
\hline \multicolumn{4}{|c|}{ Viow All } \\
\hline \multicolumn{2}{|c|}{ Students } & $8^{+}$ & : \\
\hline 8 & $\begin{array}{l}\text { bossrai254\%rgmall.com } \\
\text { (invited) }\end{array}$ & & s \\
\hline Str. & Classwork & & \\
\hline
\end{tabular}

Sample 7

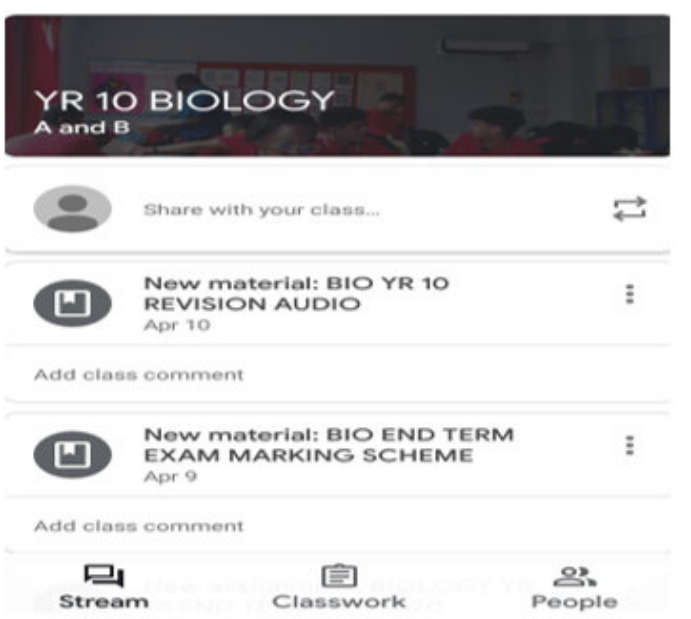

Sample 9

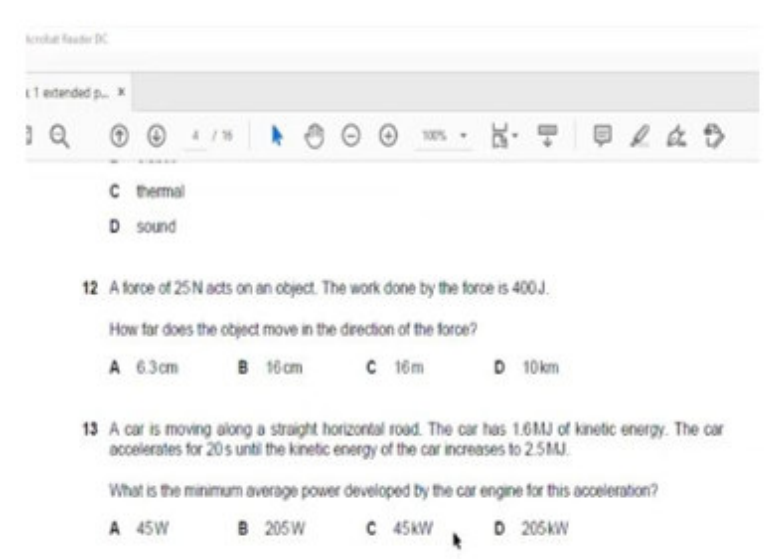

Sample 11

\section{$\equiv$ YR1O BIOLOGY $\overline{=}$}

[4] BIO YR 10 REVISION AUDIO

(D) BIO END TERM EXAM MARKING ...

(11]) NOTES ON GAS EXCHANGE, RE...

(1) GAS EXCHANGE Class nOtes

司 EXCRETION AND KIDNEY FUNCT... [4] TRANSPORT IN ANIMALS AND T

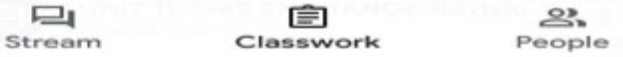

Sample 8

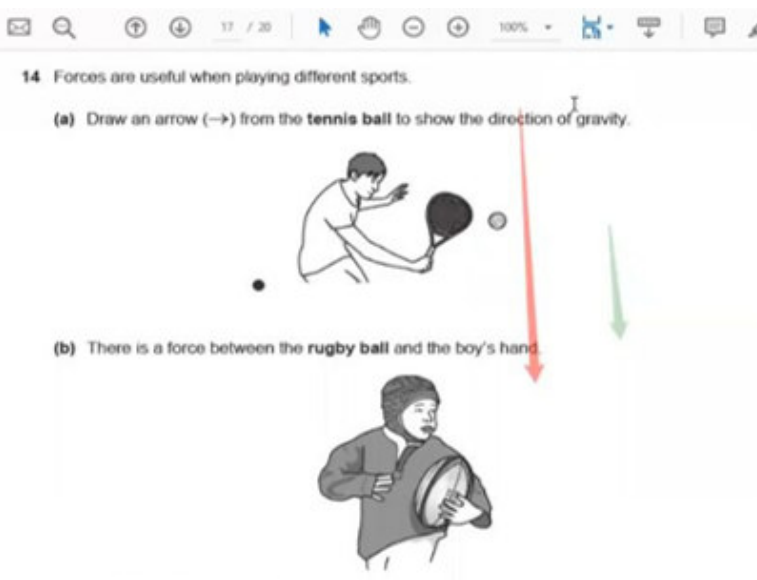

Sample 10

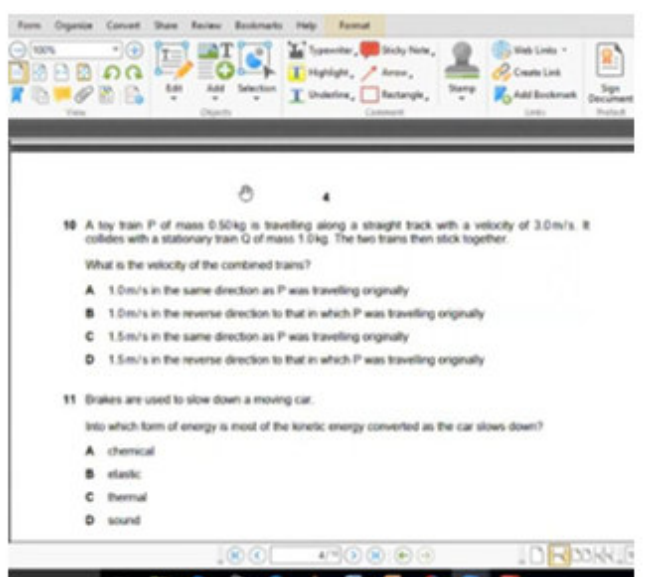

Sample12 


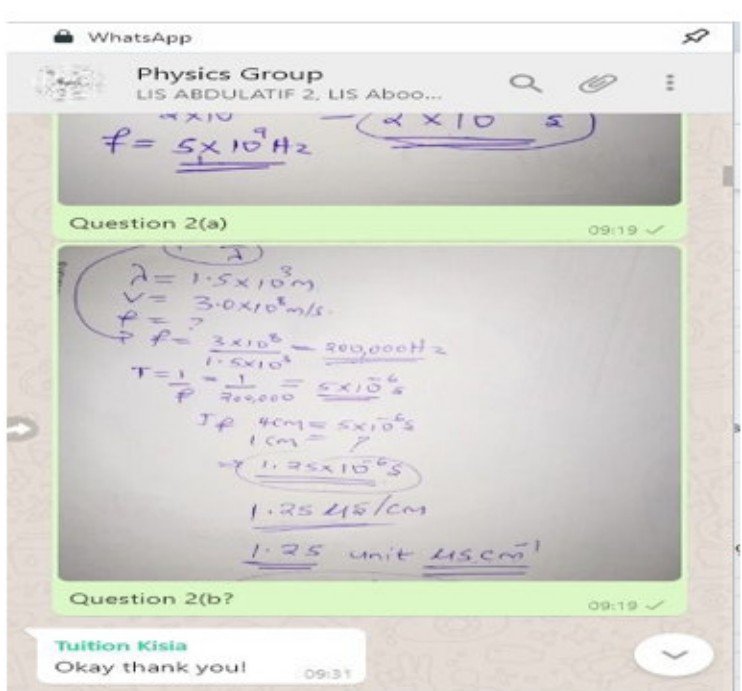

Sample 13

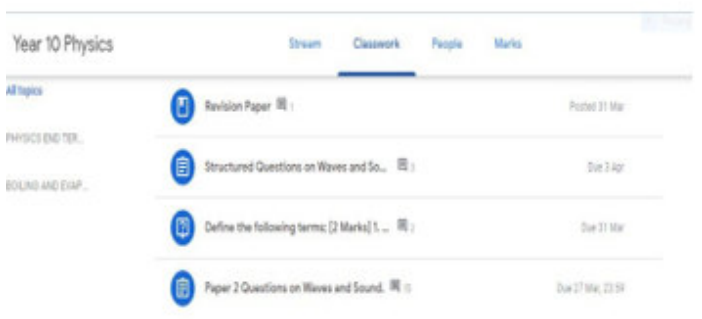

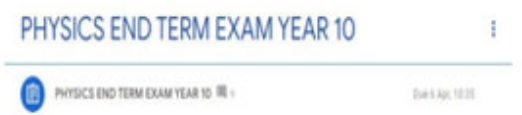

$\frac{\text { BOILING AND EVAPORATION }}{\text { n powarour on Bowng no supout_. }}$

Sample 15

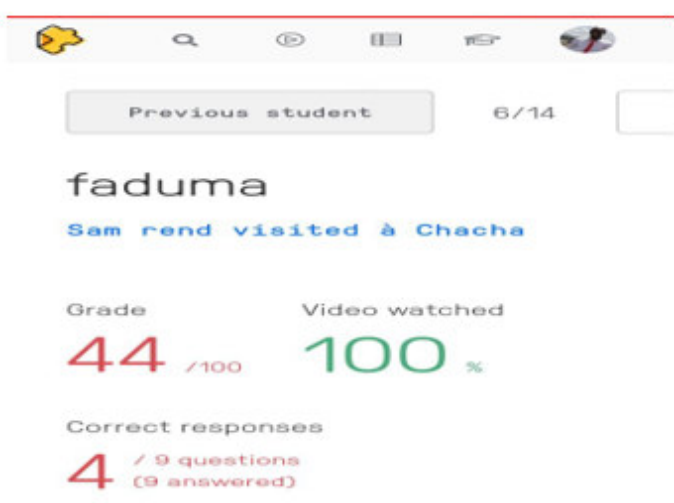

Time spent: $24 \mathrm{~min}$

Turned in: March 25th - 11:30am

Sample 17

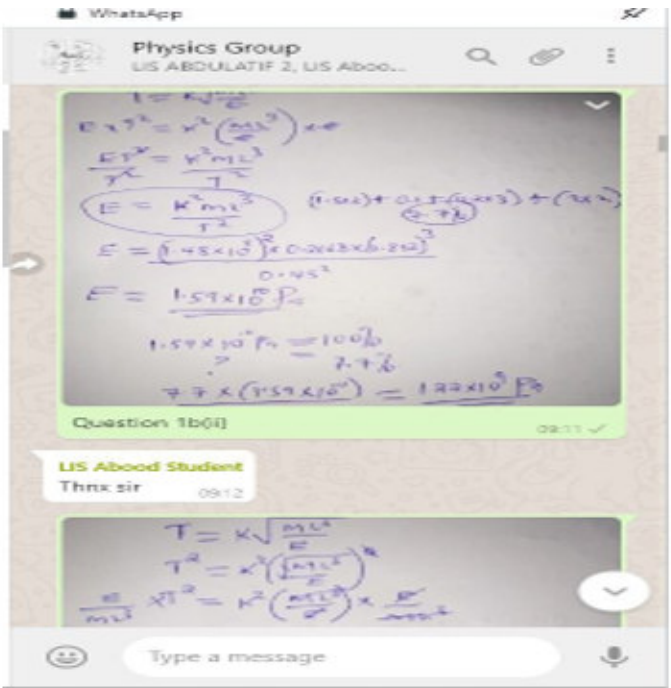

Sample 14 $\leftarrow$

Return

END TERM 2 EXAM

Amira Zahn

Graded

48 165

Amira Zahn - YEAR 10 END TERM 2

PDF Edited-A
Private comments

(2) Amira Zahn Apr 7

Sample 16

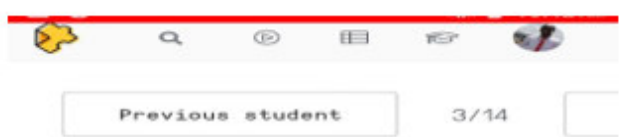

Amira Zahn

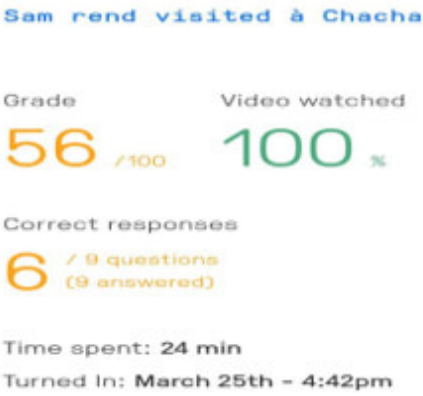

Sample 18 


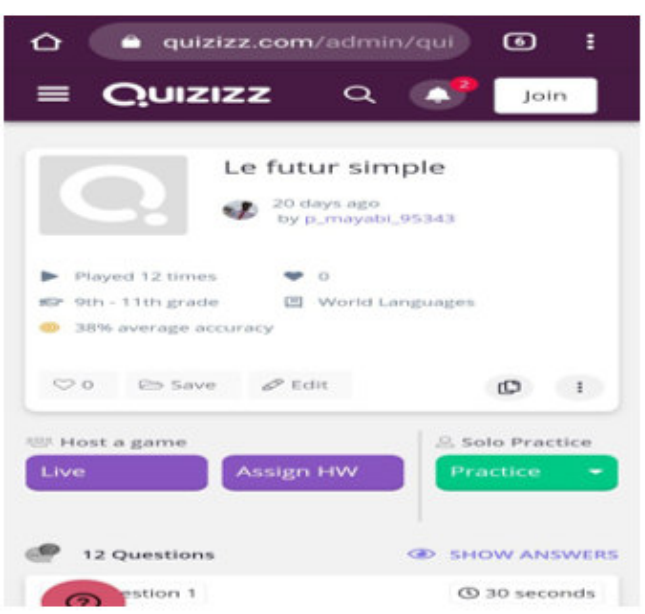

Sample 19

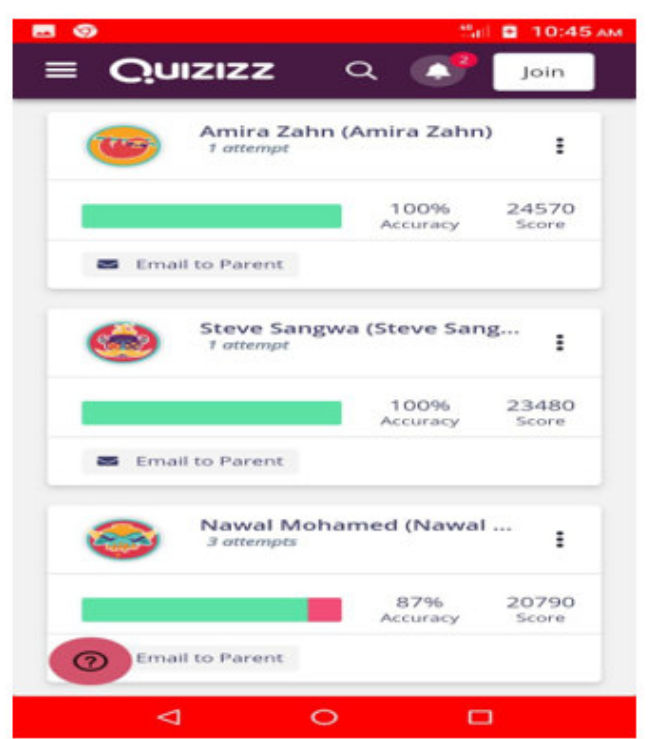

Sample 21

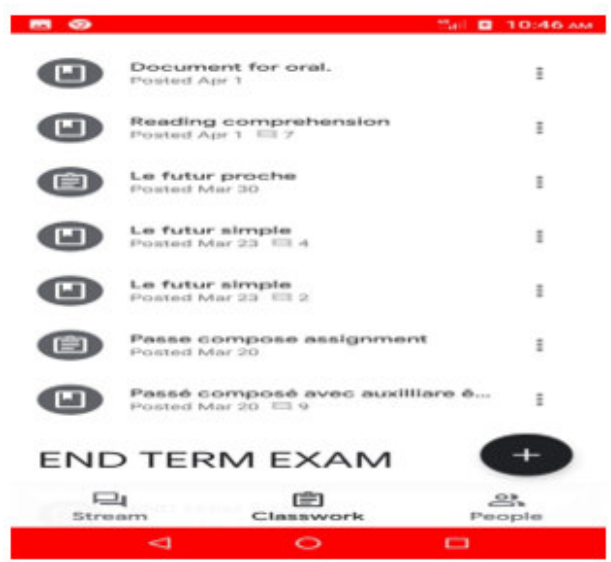

Sample 23

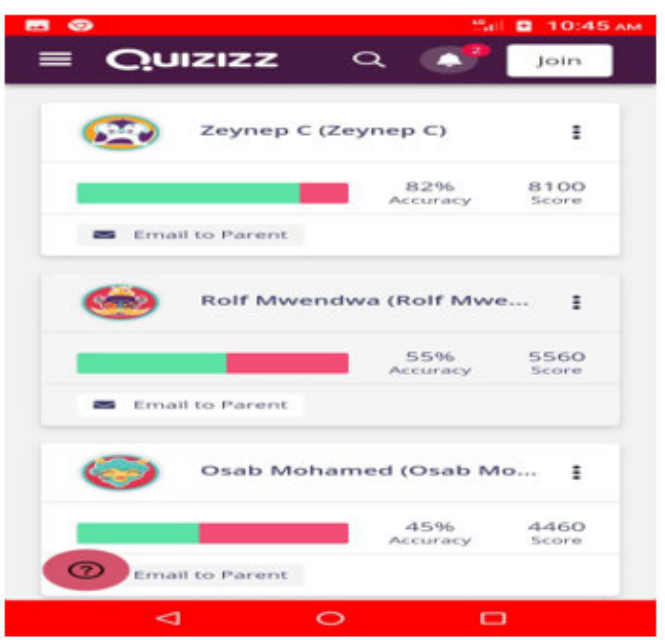

Sample 20

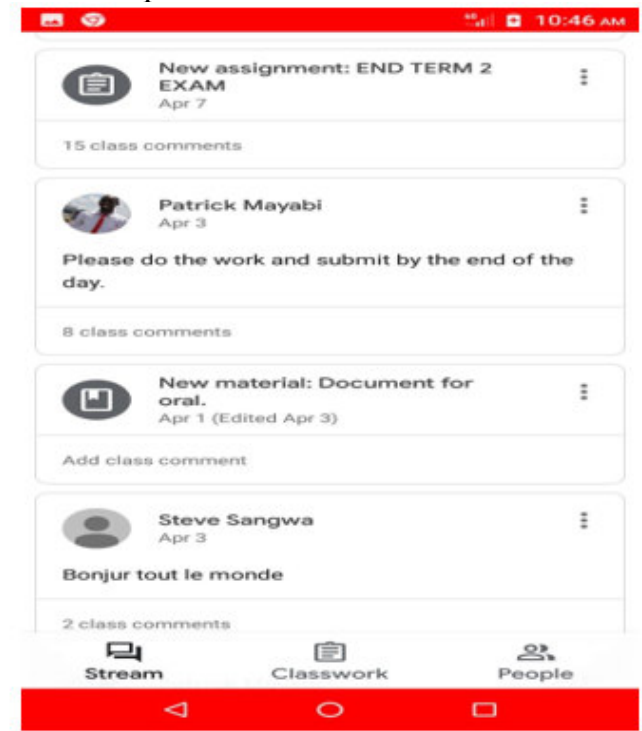

Sample 22

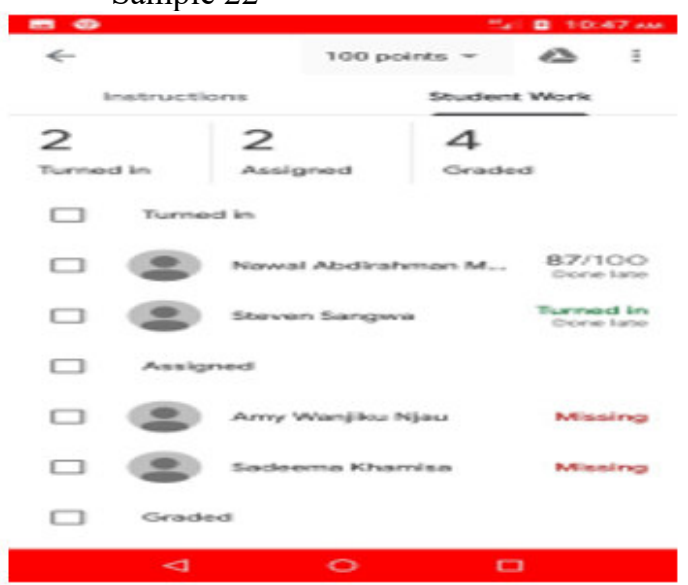

Sample 24 


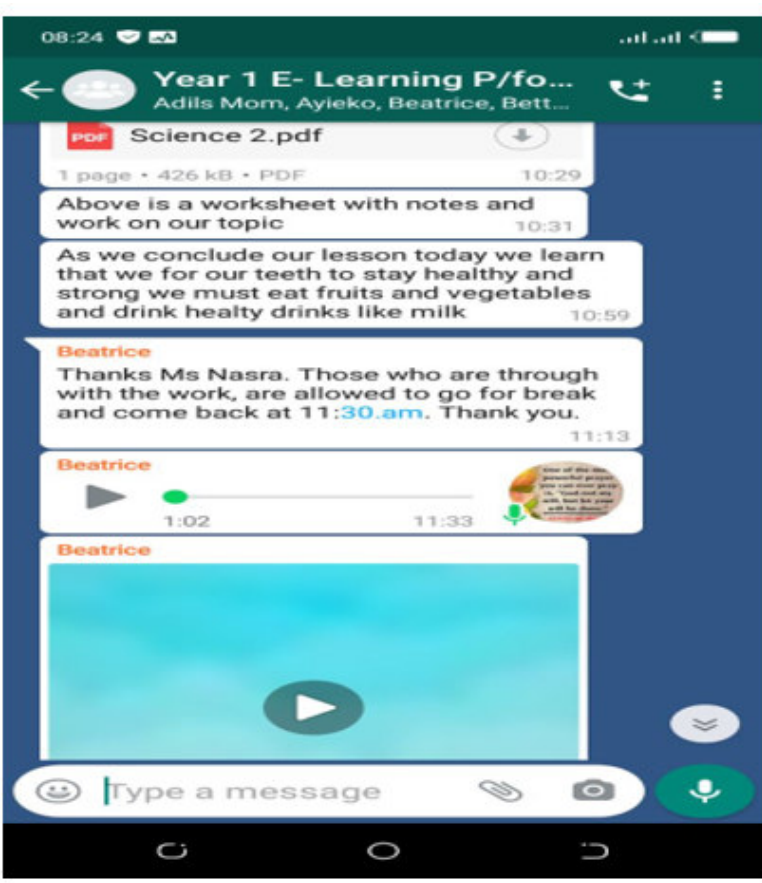

Sample 25

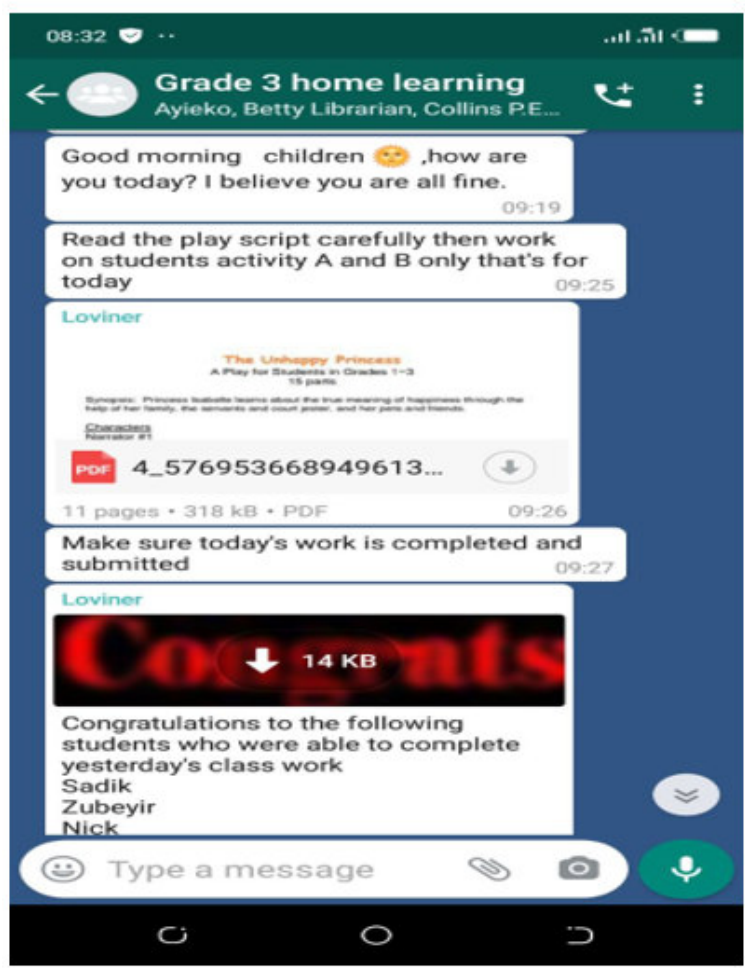

Sample 27

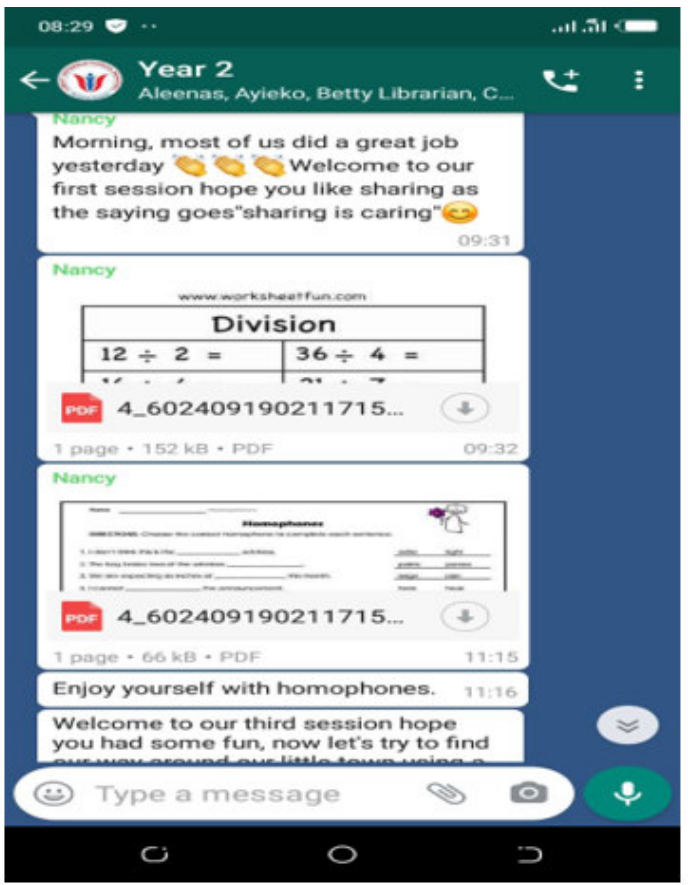

Sample 26

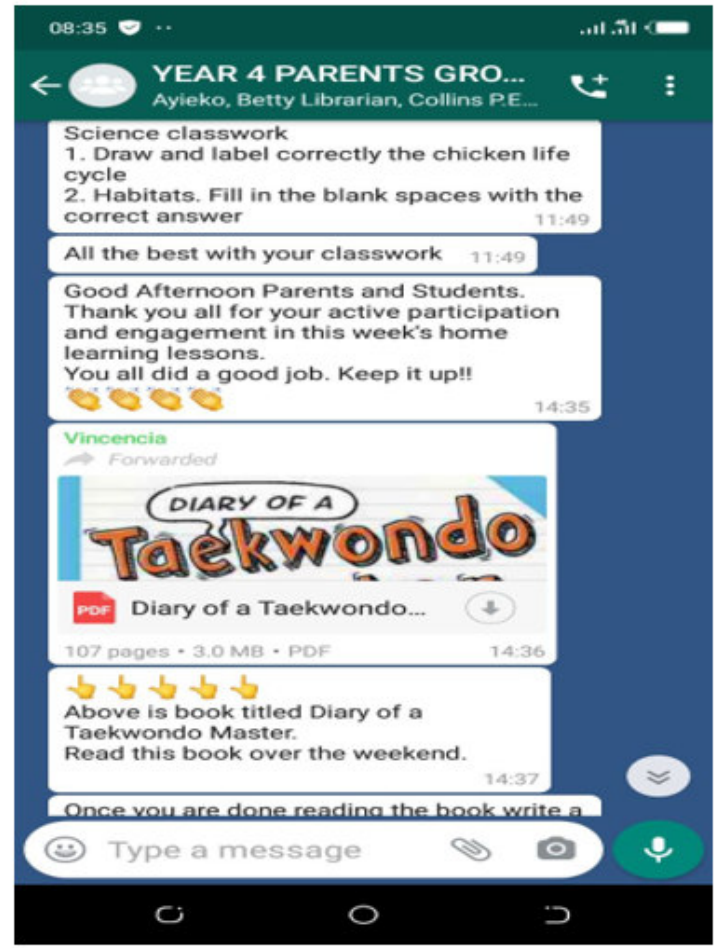

Sample 28 


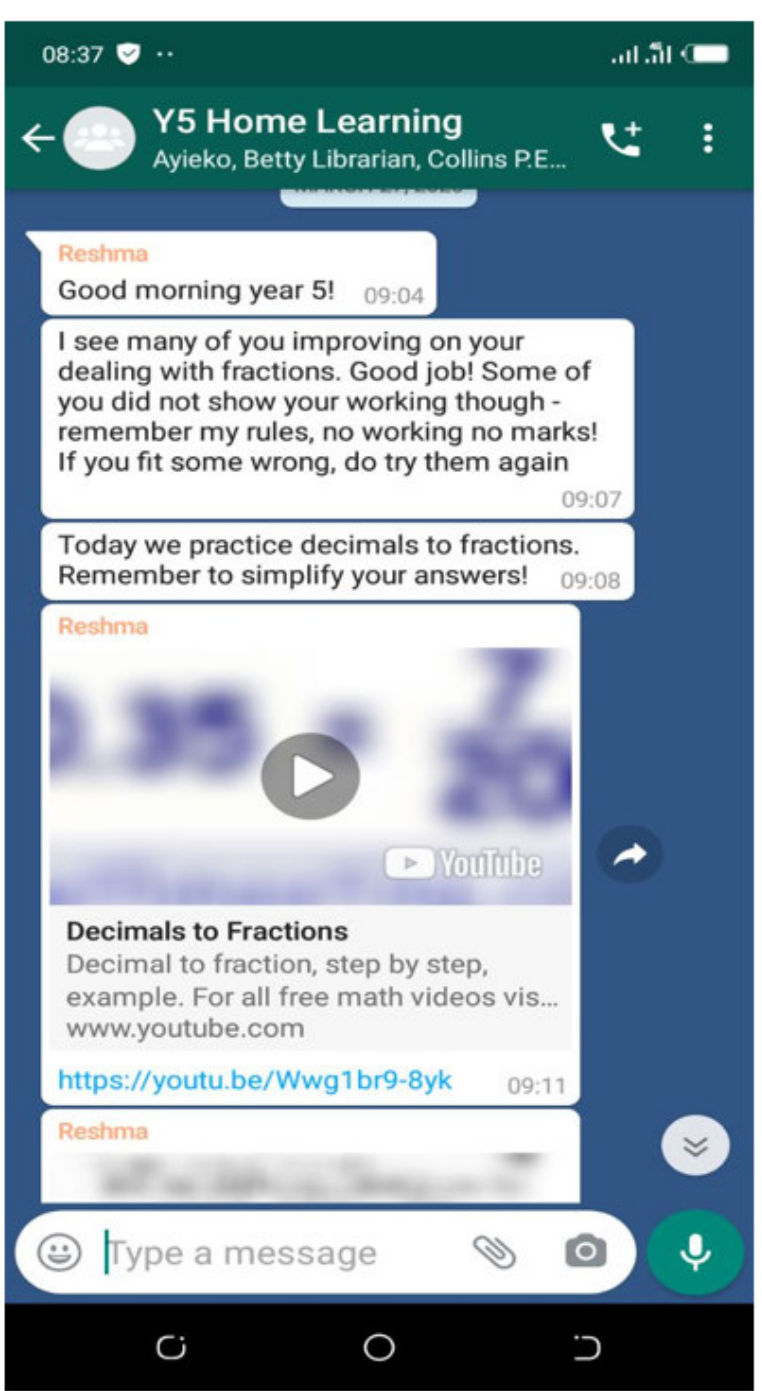

Sample 29

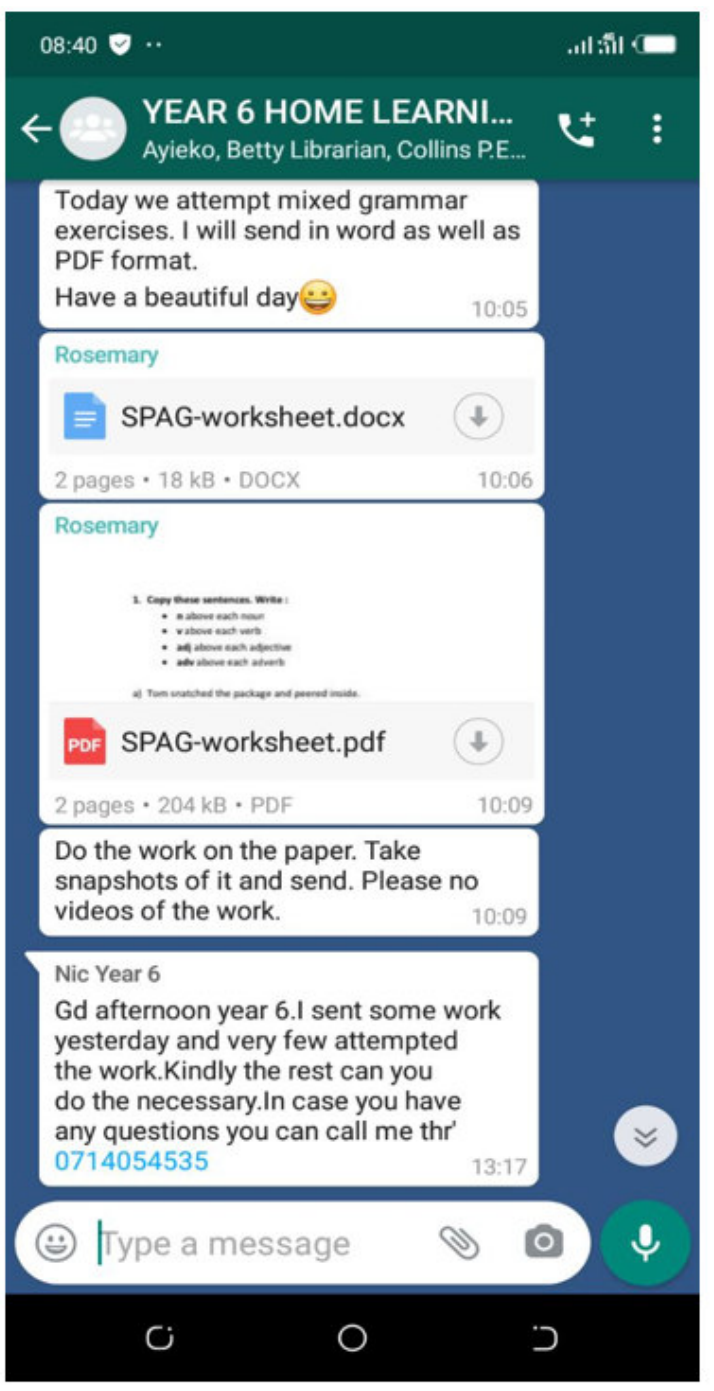

Sample 30 